\title{
「球形ドームの屋根面に作用する風圧力の性状と屋根面の動的挙動」 に対する討論
}

(小河利行, 中山昌尚, 村山 智共著 日本建築学会構造系論文報告集, 第 404 号, 1989 年 10 月揭載)

\author{
丸川比佐夫*，大 熊 武司** \\ Hisao MARUKAWA and Takeshi OHKUMA
}

大スパン屋根の耐風安全性の検討方法が関心を呼んで いる昨今, 標記論文を興味深く読ませて頂いた。私ども はかねて, 大スパン屋根の風応答予測およびその結果の 設計への反映についての問題の基本は,

(1) 屋根の各次の固有振動数が接近しがちなこと, およ び屋根部材の応力で考えると高次振動成分を簡単に無視 できないことに対する配慮

(2) とかく軽視されがちな後流の渦発生による変動風圧 力に対する配慮

(3) 後流の渦発生による変動風圧力のパワーが風の乱れ による変動風圧力のパワーに比べて高次振動数側に偏っ ていることに対する配慮

(4) 高層建築物の場合と違って, 平均風圧による静的変 位モードと変動風圧力による動的変位モ一ド間に相当の 相違が生じる恐れがあることに対する配慮

にあると考えております。

そこで, いくつか疑問の点がありましたので, 御質問 致します。

1) 視点(2)に関連して,

i ) p. 97, 左 5 行目 -8 行目において, Fig. 8 に基づい て頂部付近の変動風圧係数と気流の乱れ強さの関係は比 例関係にあると述べている（ただし，Fig. 8 にはB TYPE，C TYPE の FLOW 2 のデータが見当たらな い)が, p. 101 右 34 行目一 34 行目においては,この関
係を一般的に述べている。この関係が頂部付近以外の測 定点においても成り立つか。

ii）変動風圧のパワースペクトル (Fig. 9) の形状, 特 にパワースペクトルの形状を特徴づけるピーク振動数が 測定箇所によって大きく異なっているにもかかわらず， 変動風圧のパワースペクトル形状が変動風速のそれとよ く類似していると主張しているが，いかなる考えによる ものか。このことは, 伝達関数 $\chi(f)$ のモデル化の思想 にも関係する。

2) 視点 (2), (3), (4)に関連して,（2）式による特性 $\chi(f)$ のモデル化, 特に, 低振動数成分を高めに評価し ておけば安全側であるという判断。また，そのような評 価 (今少し言えば, 高振動数成分は逆に低めに評価して いる。）のもとで, p. 101 右側 15 行目〜19 行目あるい は計算結果による結論（1）のように主張できるか。

3) 視点(2), (4)に関連して,「変位のガストファクター」 の概念を導入することの妥当性。実際, p. 101 右側, (13) 式の下側に記されているように，ガストファクターの值 が屋根上の位置あるいは変形方向によって大きく異なっ ている場合, これによって等価静的風荷重を設定するこ とによ゙のような意味があるか。

(1990 年 5 月 25 日原稿受理)
Research Associate of Kanagawa University Professor of Kanagawa University, Dr. Engg. 